\title{
AA6061 T6 Alüminyum Alaşımında Bilyeli Dövme İşleminin Mekanik Özelliklere Etkisinin İncelenmesi
}

\author{
Ayşe Gül KOCAMAN ${ }^{1}$, Ahmet DEMIRER ${ }^{2}$ \\ ${ }^{1}$ Sakarya Uygulamalı Bilimler Üniv., Lisansüstü Eğitim Enstitüsü, Turkey \\ ${ }^{2}$ Sakarya Uygulamalı Bilimler Üniv., Teknoloji Fakültesi, Makine Müh. Turkey \\ e-posta: aysegul.kcmn1@gmail.com, ORCID ID: 0000-0001-6555-7019 \\ e-posta:ademirer@subu.edu.tr, ORCID ID: 0000-0003-1252-9203
}

Geliş Tarihi:29.06.2021; Kabul Tarihi:25.07.2021

\begin{tabular}{|c|c|}
\hline & 7 \\
\hline $\begin{array}{l}\text { Anahtar Kelimeler } \\
\text { AA6061 T6; } \\
\text { Bilyeli Dövme; } \\
\text { Bilye Boyutu; } \\
\text { Püskürtme Basıncı. }\end{array}$ & $\begin{array}{l}\text { Bilyeli dövme işlemi malzemenin mekanik ve yüzey özelliklerini iyileştirme amacıyla uygulanan bir } \\
\text { prosestir. Dövme işlemi ile birlikte malzeme yüzeyi plastik deformasyona uğrar. Bu çalışmada otomotiv, } \\
\text { savunma ve uçak sanayisi gibi birçok alanda kullanılan AA6061 T6 alüminyum alaşımına; farklı Almen } \\
\text { şiddetlerinde S230 (0.6 mm) ve S330 (0.84 mm) çelik bilyeler ile dövme işlemi uygulanmıştır. Bu işlem } \\
\text { sonucunda malzemenin mekanik ve yüzey özellikleri incelenmiştir. AA6061 T6 alüminyum alaşımının } \\
\text { bilyeli dövme ile (\%100 yüzey örtme oranında) çekme dayanımında \%1 ile \%3.8 arasında artış meydana } \\
\text { gelmiştir. Yüzey örtme oranı } 6 \text { bar püskürtme basıncında \%200'e çıkartıldığında \%100 yüzey örtme } \\
\text { oranına göre çekme dayanımı; küçük bilyede ( } 230 / 0.6 \mathrm{~mm}) \% 2.3 \text {, büyük çaplı bilyede (S330/0.84) \%0.7 } \\
\text { artış göstermiştir. Püskürtme basıncının artması ile her iki bilye çapında yüzey pürüzlülük değerleri artış } \\
\text { göstermiştir. Çalışmada ayrıca yüzey özelliklerinin incelenmesi için SEM görüntüsü ele alınarak bilyeli } \\
\text { dövmenin malzeme yüzeyindeki plastik deformasyonu incelenmiştir. }\end{array}$ \\
\hline
\end{tabular}

\section{Investigation of Effect of Shot Peening on the Mechanical Properties of AA6061 T6 Aluminum Alloy}

\begin{abstract}
Shot peening is a process applied to improve the mechanical and surface properties of the material. With the forging process, the material surface undergoes plastic deformation. In this study, to AA6061 T6 aluminum alloy that used in many areas such as automotive, defense and aircraft industry; shot peening was applied at different Almen intensities obtained with S230 $(0.6 \mathrm{~mm})$ and S330 $(0.84 \mathrm{~mm})$ stainless steel balls. At the end of this process, the mechanical and surface properties of the material were examined. With the ball forging (100\% surface coverage) of AA6061 T6 aluminum alloy, an improvement in tensile strength from $1 \%$ to $3.8 \%$ occurred. When the surface coverage ratio is increased to $200 \%$ at 6 bar injection pressure, tensile strength compared to $100 \%$ surface coverage; increased $2.3 \%$ for small ball $(\mathrm{S} 230 / 0.6 \mathrm{~mm}$ ) and $0.7 \%$ for large diameter ball (S330/0.84). As the injection pressure increased, the surface roughness values of both ball types increased. For the surface evaluation, the plastic deformation of the shot peening on the material surface was investigated with SEM images.
\end{abstract}

(C) Afyon Kocatepe Üniversitesi 


\section{Giriş}

Bilyeli dövme, metalik malzemelerin yüzey ve yüzey altı özelliklerini geliştirmek için kullanılan soğuk şekil verme yöntemidir (Varol, 1990). Yüksek hızlarda fırlatılan küçük çaplı bilyelerin malzeme yüzeyine tekrarlı çarpması sonucu plastik deformasyon tabakası oluşturur (Alkan, 2016) Bu durum malzemenin tane yapılarını incelterek, çekme dayanımında artış, yüzeyde artık gerilme oluşumu, yüzey ve yüzey altı bölgelerinde sertlik artışı olarak gözlemlenir. Bilyeli dövme prosesinde bilyeler vasıtasıyla malzemeye kinetik enerji aktarımı sağlanmaktadır. Bu enerjinin ölçülmesi için Almen testi geliştirilmiştir. Almen şiddeti; bilye çapı, bilye cinsi, püskürtme basıncı, dövme süresi ve yüzey örtme oranına bağlı olarak değişir (Avcu E. , 2018). Almen şiddeti arttıkça plastik deformasyon kalınlığı da artmaktadır (Ünal \& Varol, 2014). Bilyeli dövme otomotiv ve havacılık sektörlerinde sıklıkla kullanılan ucuz ve erişilebilir bir yöntemdir.

Alüminyum malzemeler yüksek korozyon direnci, yüksek özgül dayanım, kolay işlenebilirlik, hafiflik özellikleriyle çelikten sonra en yaygın kullanılan mühendislik malzemeleridir. Alüminyum çelik ile kıyaslandığında üç kat daha hafiftir enerji tasarrufunun önem kazandığı savunma sanayinde, trenler, uçaklar, gemiler ve otomobiller gibi pek çok alanda tercih edilmektedir (Başer, 2012). Son yıllardaki gelişmeler ile birlikte askeri araçlarda hız ve manevra kabiliyetinin arttırılması önemli bir konu olmuştur. Çelik malzemelerin yerini alacak alüminyum alaşımlarının mekanik özelliklerinin iyileştirilmesi bu çalışmanın başlıca amaçlarındandır. 6xxx serisi alüminyum alaşımları magnezyum ( $\mathrm{Mg}$ ) ve silisyum (Si) içerir. Kaynak edilebilme kabiliyetleri yüksektir. Bu özellik üretim masraflarını düşürür (Coşkun, 2002).

Alüminyum alaşımlar ile yapılan bilyeli dövme işlemleri incelendiğinde Chen ve arkadaşları farklı basınçlarda dövülen AA6061 malzemesini incelemiştir. Basınç arttıkça yüzey pürüzlülüğü, plastik deformasyon kalınlığı ve korozyon direncinde artış olduğunu gözlemlemişlerdir (Chen, ve diğerleri, 2014). Alkan, AA1040 ve AA2024 alüminyum alaşımları üzerine yaptığı doktora çalışmasında S230 ve S460 bilyeler ile dövme işlemi gerçekleştirmiş ve akma sınıında artış elde ederken malzemelerin kopma uzamasında azalma olduğunu kaydetmiştir (Alkan, 2014). Sathyajith; lazer ile dövme işlemini AA6061 T6 alüminyum alaşımına uygulamış ve yüzeyde meydana gelen plastik deformasyonun bilye atış yoğunluğu ile birlikte arttığını ve malzemede mikrosertliğin $1.2 \mathrm{~mm}$ artış gösterdiğini tespit etmiştir (Sathyajith \& Kalainathan, 2012). Markovina ve arkadaşları, bilyeli dövme parametrelerinden nozul açısı ve nozul mesafesinin AA2024-T3 üzerine etkisini incelemişlerdir. Bilyeli dövme parametrelerinin hatalı seçilmesi durumunda malzeme yüzeyinde aşırı soyulmaya neden olacağını belirtmişlerdir (Markovina, Blagojević, \& Ban, 2008). Patil ve arkadaşları yaptıkları derlemede bilyeli dövmenin alüminyum alaşımlarının mekanik özelliklerine etkisini inceleyen çalışmalara değinmişlerdir. Bilyeli dövmenin; çekme dayanımı, yorulma ömrü ve korozyon direnci ile doğrudan ilgili olduğunu belirtmişledir (Patil, Shrikant, S., \& S., 2018). Günümüzde farklı alüminyum alaşımlarında ve farklı dövme türlerinde çok sayıda çalışma devam etmektedir.

Bilyeli dövme işleminde farklı parametreler, dövülen malzemenin özelliklerini doğrudan etkilemektedir. Bu parametreler; bilye çapı, bilye türü, püskürtme basıncı, püskürtme açısı, yüzey örtme oranı, dövme süresi, püskürtme açısı, nozul çapı ve mesafesidir (Avcu E. , 2018). Yapılan bu çalışmada, AA6061 T6 alüminyum alaşımına dövme işlem parametreleri olarak iki farklı bilye çapı ve üç farklı püskürtme basıncı kullanılmıştır. Bu parametrelerin malzemenin mekanik ve yüzey özelliklerine olan etkisi incelenmiştir.

\section{Malzeme ve Yöntem}

\subsection{Malzeme}

Bu çalışmada incelemeye değer olarak otomotiv, savunma ve uçak sanayisi gibi birçok alanda 
kullanılan AA6061 T6 malzemesi seçilmiştir. T6 alüminyum malzemenin maksimum akma mukavemetini sağlamaya yönelik ısıl işlem gördüğünü göstermektedir. Tablo 1'de kimyasal özellikleri ve Tablo 2'de mekanik özellikleri verilen malzeme $320 \times 320 \times 3.17 \mathrm{~mm}$ boyutlarında levha formunda hazırlanmıştır.

Tablo 1. AA6061 T6 Alüminyum alaşımının kimyasal özellikleri

\begin{tabular}{ccccccccccc}
\hline Elementler & $\mathrm{Si}$ & $\mathrm{Fe}$ & $\mathrm{Cu}$ & $\mathrm{Mn}$ & $\mathrm{Mg}$ & $\mathrm{Cr}$ & $\mathrm{Zn}$ & $\mathrm{Ti}$ & $\mathrm{Diğer}$ & $\mathrm{Al}$ \\
\hline Kütlece \% & 0.68 & 0.44 & 0.24 & 0.14 & 0.94 & 0.18 & 0.06 & 0.04 & 0.03 & Kalan \\
\hline
\end{tabular}

Tablo 2. AA6061 T6 Alüminyum alaşımının mekanik özellikleri

\begin{tabular}{ccccc}
\hline Temper & $\begin{array}{c}\text { Akma Mukavemeti } \\
\text { (MPa) }\end{array}$ & $\begin{array}{c}\text { Çekme Mukavemeti } \\
\text { (MPa) }\end{array}$ & $\begin{array}{c}\text { Uzama } \\
\text { (\%) }\end{array}$ & $\begin{array}{c}\text { Sertlik } \\
\text { (Vickers-HV) }\end{array}$ \\
\hline T6 & 270 & 310 & 16 & 86 \\
\hline
\end{tabular}

\subsection{Yöntem}

Bilyeli dövme işlemi SGM-1000G marka vakumlu tip bilyeli dövme makinesinde yapılmıştır. Manuel ayarlamalı olan makine için geliştirilen düzenek ile plakalara bilyeli dövme işlemi uygulanmıştır (Şekil 1).
Çalışmada kullanılan bilyeler SAE tarafından belirlenen standartlara uygun olarak seçilmiştir. Bilye gösterimindeki "S" kodu çelik bilye oluğunu, "S230"daki rakam ise nominal çapın inç değerinin 10000 ile çarpılmasını gösterir. Bilyelere ait fiziksel özellikler Tablo 3'te verilmiştir.

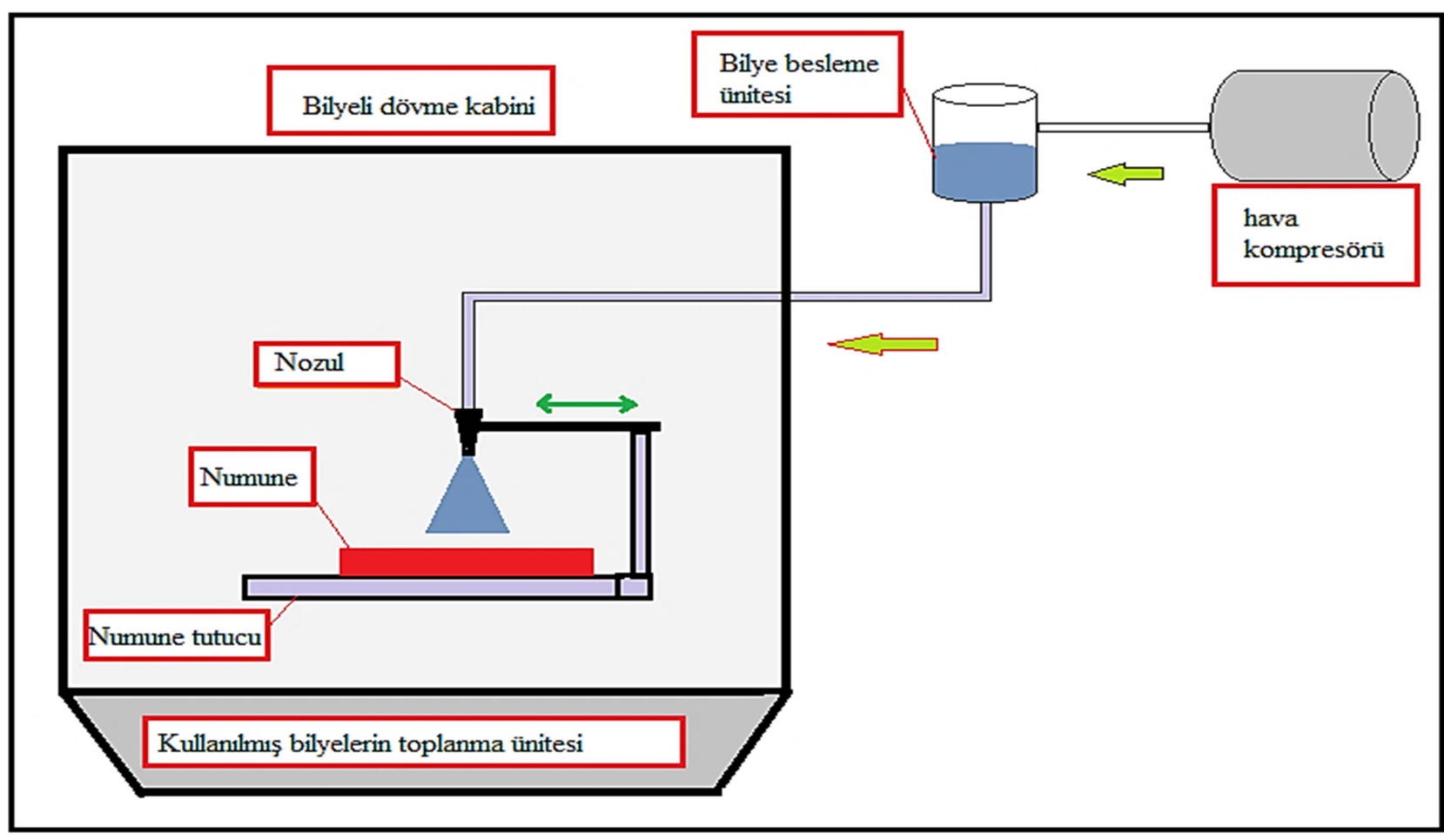

Şekil 1. Bilyeli dövme düzeneği 
Tablo 3. Bilye özellikleri (Fetaş Metalurji , 2021)

\begin{tabular}{|c|c|c|c|c|c|c|}
\hline \multirow{2}{*}{ SAE no } & \multirow{2}{*}{$\begin{array}{c}\text { Nominal } \\
\text { çap } \\
(\mathrm{mm})\end{array}$} & \multirow{2}{*}{$\begin{array}{c}\text { Bilye } \\
\text { sertliği } \\
\text { (HRC) }\end{array}$} & \multirow{2}{*}{$\begin{array}{l}\text { Özgül } \\
\text { Ağırlık } \\
\left(\mathrm{g} / \mathrm{cm}^{3}\right)\end{array}$} & \multirow{2}{*}{ Kristal Şekli } & \multicolumn{2}{|c|}{ SEA J444 Elek Analizi } \\
\hline & & & & & Elek (mm) & Tolerans \\
\hline \multirow{4}{*}{ S230 } & \multirow{4}{*}{0.60} & \multirow{4}{*}{$40-55$} & \multirow{4}{*}{7.2} & \multirow{4}{*}{ Martenzitik } & 1.0018 No Elekten & Tamamı \\
\hline & & & & & 0.8520 No Elekten & $\max . \% 10$ \\
\hline & & & & & 0.6030 No Elekten & $\min . \% 85$ \\
\hline & & & & & 0.5035 No Elekten & $\min . \% 97$ \\
\hline \multirow{4}{*}{ S330 } & \multirow{4}{*}{0.84} & \multirow{4}{*}{$40-55$} & \multirow{4}{*}{7.2} & \multirow{4}{*}{ Martenzitik } & 1.4014 No Elekten & Tamamı \\
\hline & & & & & 1.1816 No Elekten & $\max . \% 5$ \\
\hline & & & & & 0.8520 No Elekten & $\min . \% 85$ \\
\hline & & & & & 0.7125 No Elekten & $\min . \% 96$ \\
\hline
\end{tabular}
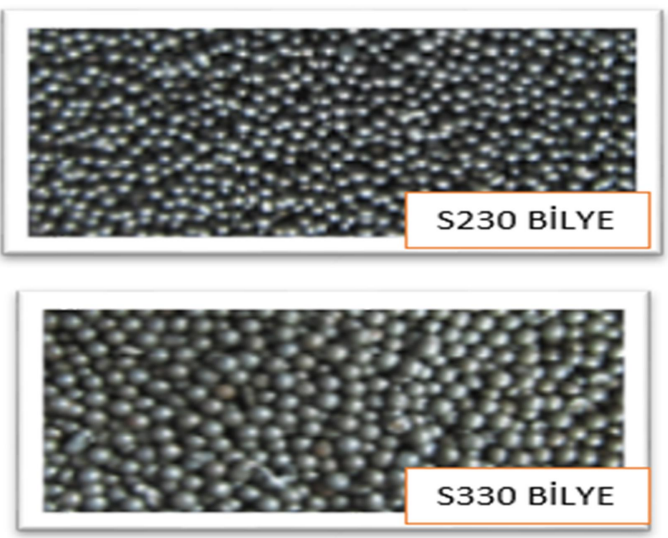

Şekil 2. S230 ve S330 bilye görünümleri (Fetaş Metalurji , 2021)

Bilyeli dövme işleminde fırlatılan bilyelerin aktardığı kinetik enerjiyi ölçmek için Almen şiddeti kullanılır. $\mathrm{Bu}$ yöntemde standart şeritler kullanılır. Bilyeli dövme ile birlikte şeritte konveks eğilme meydana gelir. Almen şiddeti deformasyona uğrayan şeritlerde meydana gelen eğriliğinin yüksekliği olup Almen ölçüm cihazı ile belirlenir (Şekil 4). Bilyeli dövme işleminin Almen şiddetinin ölçülmesi için farklı sürelerde dövme işlemi tekrarlanır. Dövme süresi iki katına çıkarıldığında şeritte meydana gelen eğri yüksekliği \%10'dan daha az ise \%100 yüzey örtme oranına ulaştığı kabul edilir. Almen şiddetinin ölçülmesinde standart şerit tipleri (N:hafif dövme şiddeti, A:orta dövme şiddeti, C:yüksek dövme şiddeti) kullanılmaktadır. Almen şeridi tutucuya (Şekil 3) sabitlenerek dövme işlemi gerçekleştirilir (Alkan, 2014).

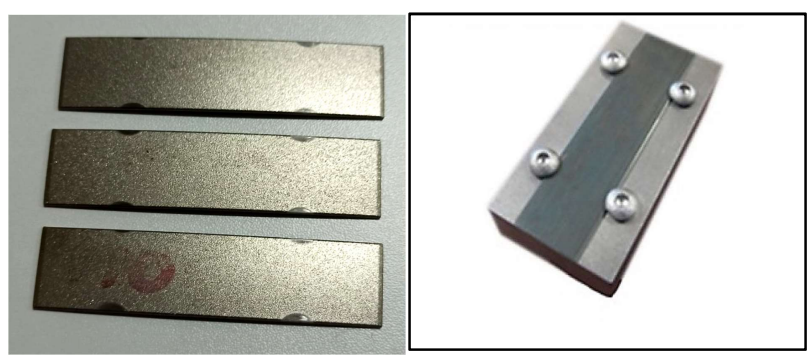

Şekil 3. Almen şeritleri ve Almen tutucu

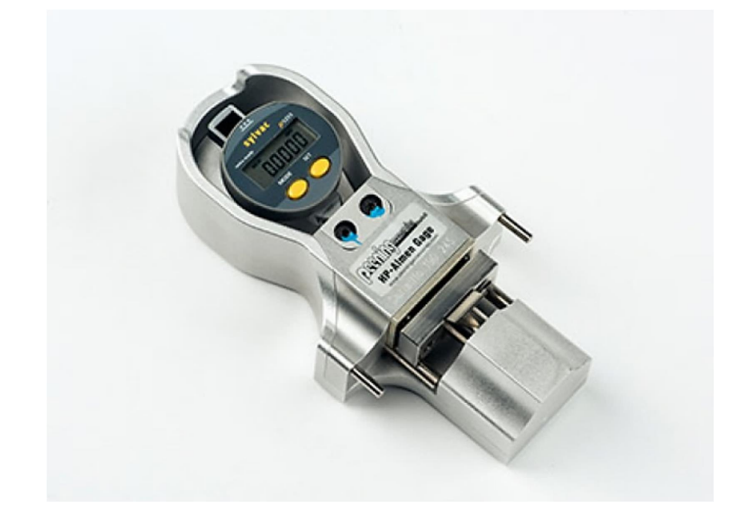

Şekil 4. Almen ölçüm cihazı

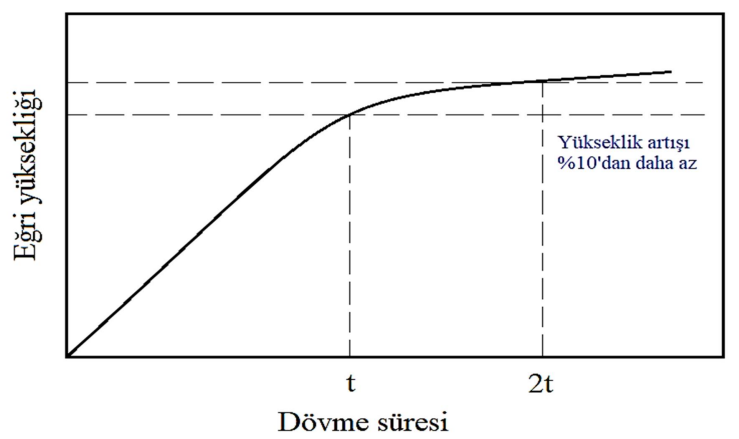

Şekil 5. Dövme süresi-eğrilik yüksekliği grafiğinden yüzey örtme oranı tayini (Ay \& Sakin, 1988) 
Çalışmada işlem parametreleri iki farklı tane büyüklüğüne sahip (S230 ve S330) bilyelerle, üç farklı basınçta (4, 6 ve 8 bar) ve \%100 yüzey örtme oranında dövülmüştür. Ayrıca yüzey örtme oranının bilyeli dövmedeki etkisinin incelenmesi amacıyla 6 bar basınçta yapılan dövme işlemi yüzey örtme oranı \%200'e çıkartılarak tekrar uygulanmıştır. Tablo 4'de belirlenen parametreler ve bu parametreler sonucunda elde edilen Almen şiddeti değerleri mevcuttur. Eğrilik yüksekliği 100 ile çarpılarak Almen şiddeti ifade edilir (Ay \& Sakin, 1988).

Tablo 4. Bilyeli dövme parametreleri

\begin{tabular}{|c|c|c|c|c|c|c|}
\hline Malzeme & $\begin{array}{c}\text { Bilye } \\
\text { ölçüsü }\end{array}$ & $\begin{array}{c}\text { Yüzey örtme } \\
\text { oranı (\%) }\end{array}$ & $\begin{array}{c}\text { Püskürtme } \\
\text { Basınç } \\
\text { (bar) }\end{array}$ & $\begin{array}{l}\text { Eğri yüksekliği } \\
\text { (inç) }\end{array}$ & $\begin{array}{l}\text { Süre } \\
\text { (sn) }\end{array}$ & $\begin{array}{l}\text { Almen } \\
\text { Şiddeti }\end{array}$ \\
\hline \multirow{8}{*}{ AA6061 T6 } & \multirow{3}{*}{ S230 } & 100 & 4 & 0.146 & 51 & $14 \mathrm{~A}$ \\
\hline & & 100 & 6 & 0.157 & 64 & $16 \mathrm{~A}$ \\
\hline & & 100 & 8 & 0.187 & 72 & $18 \mathrm{~A}$ \\
\hline & S230 & 200 & 6 & 0.157 & 128 & $16 A$ \\
\hline & \multirow{3}{*}{ S330 } & 100 & 4 & 0.183 & 58 & $18 \mathrm{~A}$ \\
\hline & & 100 & 6 & 0.245 & 70 & $24 \mathrm{~A}$ \\
\hline & & 100 & 8 & 0.276 & 81 & $28 \mathrm{~A}$ \\
\hline & S330 & 200 & 6 & 0.245 & 140 & $24 A$ \\
\hline
\end{tabular}

Çekme numuneleri, çekme testine hazırlık için Tablo 4'deki dövme işlemi sonrasında fiber lazer kesim makinesiyle (HD-F 3015) hazırlanmıştır. Tablo 5 'te çekme test numunesi hazırlamak için kesim parametreleri verilmiştir.

Tablo 5. HD-F 3015 fiber lazer kesim makinesi parametreleri

\begin{tabular}{lc}
\hline Hız (mm/min) & 5000 \\
\hline Nozul mesafesi (mm) & 1 \\
\hline Gaz basıncı (bar) & 15 \\
\hline Lazer güç (W) & 3000 \\
\hline Frekans (Hz) & 5000 \\
\hline
\end{tabular}

Çekme numumelerinin boyutları Şekil 6'da verilmiştir. Hazırlanan çekme numuneleri LPM-3M polisaj makinası ile 120 meshlik zımparalar takılarak lazer kesimi sırasında oluşan kesim izleri düzeltilmiştir. Çekme deneyleri ise SHIMADZU AGIC çekme test cihazında gerçekleştirilmiştir. Bilyeli dövme işlemi öncesi ve sonrası yüzey pürüzlülüğünün ölçülmesi için ART300 cihazı (Şekil 7) kullanılmıştır. Bilyeli dövme ile yüzey özelliklerinin incelenmesi için dövülen plaka formundaki malzemelerden $10 \times 10 \mathrm{~mm}$ boyutunda numuneler alınarak JEOL JSM-6060LV taramalı elektron mikroskopunda (SEM) incelenmiştir.

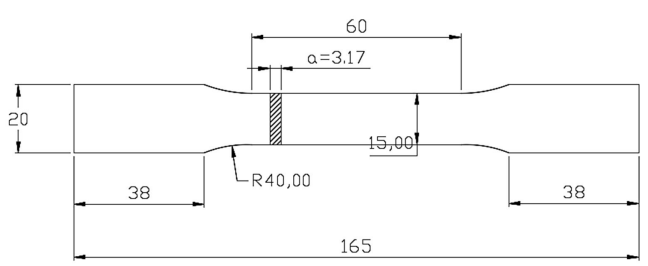

Şekil 6. Çekme numunesi boyutları (ISO 6892-1)

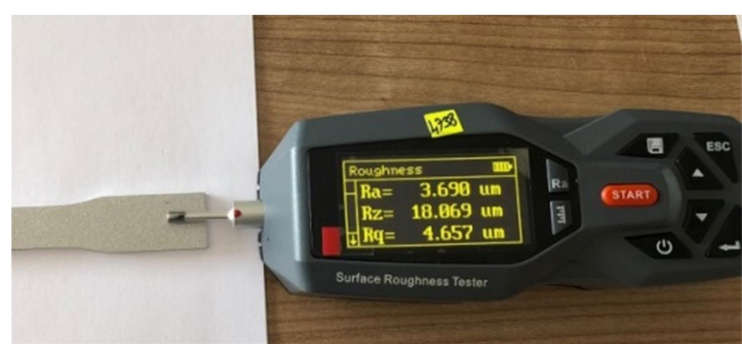

Şekil 7. Yüzey pürüzlülük ölçümü

\section{Deneysel Bulgular ve Tartışma}

\subsection{Bilyeli dövme parametrelerinin çekme mukavemetine etkisi}

AA6061 T6 alüminyum alaşımının S230 ve S330 çelik bilyeler kullanılarak 4,6 ve 8 bar püskürtme 
basıncında bilyeli dövme işlemi neticesinde kaydedilen çekme testi sonuçları Şekil 8 ve Tablo $6^{\prime}$ da yer almaktadır. Bilyelerin yüzeye uyguladıkları bombardımanın etkisi mekanik özellikleri doğrudan etkilemiştir. Çekme mukavemetindeki artış Almen şiddetiyle doğru orantılı bir şekilde artmıştır.
Buradaki artış pekleşme sonucunda yüzeyde meydana gelen artık basma gerilmesi oluşumu ve tane yapılarındaki plastik deformasyonlar ile ilişkilendirilebilir (Avcu E. , 2018).
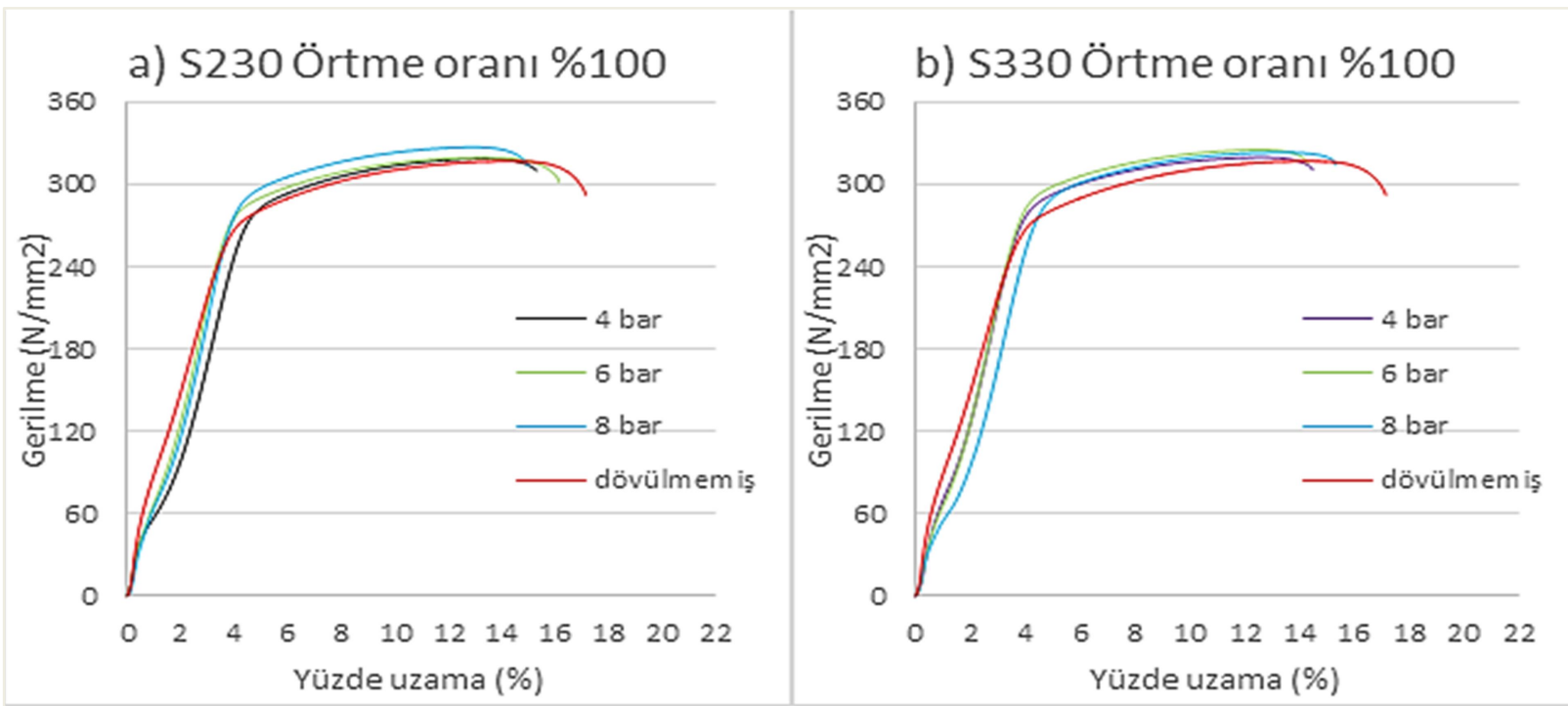

Şekil 8. Çekme testi sonuçları a)S230 bilye ile \%100 yüzey örtme oranında b)S330 bilye ile \%100 yüzey örtme oranında

Numunelerdeki mikro sertlik değerleri, iki tarafı dövülmüş numunelerin yanal kesitleri $(3.17 \mathrm{~mm})$ üzerinden alınmıştır. Ölçümler dıştan içe doğru gerçekleştirilmiştir. Tablo $6^{\prime}$ da dövülmüş yüzey sertliği, iki yüzeyden alınan sertlik değerlerinin ortalaması olup iki yüzey arasındaki fark yaklaşık \%1-2 kadar tespit edilmiştir. Ayrıca numunelerdeki kesitin orta öz kısmından da ölçümler alınarak meydana gelen değişim verilmiş̧ir. Püskürtme basıncı arttıkça yüzeylerde sertlik artışı görülürken, öz kısımda ancak yüksek püskürtme basıncında çok düşük bir artış gözlenmiştir. Bu mikro sertlik değerleri \%100 örtücülük oranında alınan değerlerdir.

Tablo 6. Çekme mukavemeti ve Mikro sertlik değerleri (Örtücülük oranı:100)

\begin{tabular}{cccccc}
\hline $\begin{array}{c}\text { Malzeme } \begin{array}{c}\text { ve } \\
\text { Bilyeler }\end{array} \\
\text { Dövülmemiş } \\
\text { AA6061 T6 }\end{array}$ & $\begin{array}{c}\text { Püskürtme } \\
\text { Basıncı } \\
\text { (bar) }\end{array}$ & $\begin{array}{c}\text { Çekme } \\
\text { Mukavemeti } \\
\text { (MPa) }\end{array}$ & $\begin{array}{c}\text { Uzama } \\
\text { (\%) }\end{array}$ & $\begin{array}{c}\text { Mikrosertlik } \\
\text { HV } \\
\text { (Dövülmüş yüzey) }\end{array}$ & $\begin{array}{c}\text { Mikrosertlik } \\
\text { HV }\end{array}$ \\
\hline (Numune orta kesiti)
\end{tabular}




\subsection{Bilyeli dövme parametrelerinin yüzey pürüzlülüğüne etkisi}

Bilyeli dövme işlemi bu çalışmada mekanik özelliklerin iyileştirilmesine yönelik yapılmaktadır. Fakat parça yüzeyinin işlem sonunda kullanılacağı yere uygunluk açısından da değerlendirilmesi yapılmıştır. Bilyalı dövme işlemi sonucunda numunelerin yüzey pürüzlük değerinde artı̧̧ meydana gelmiştir. S230 ve S330 çelik bilyelerde yapılan dövme sonucunda Ra (ortalama pürüzlülük) değerinde meydana gelen değişim Şekil 9'da verilmiştir.

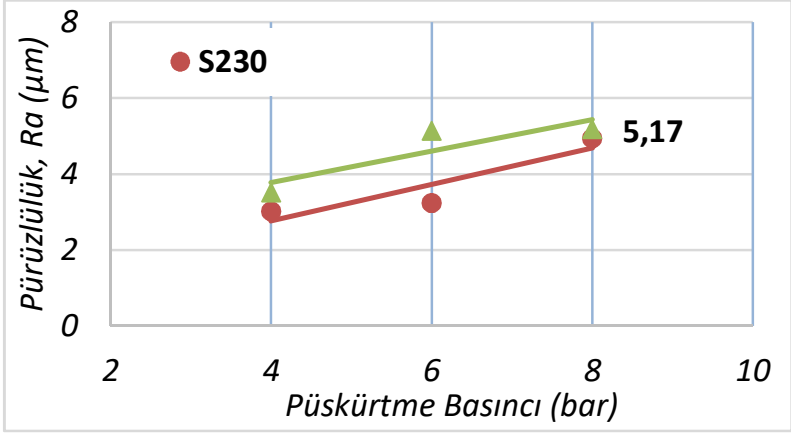

Şekil 9. AA6061 T6 malzemenin farklı basınçlardaki yüzey pürüzlülük değeri
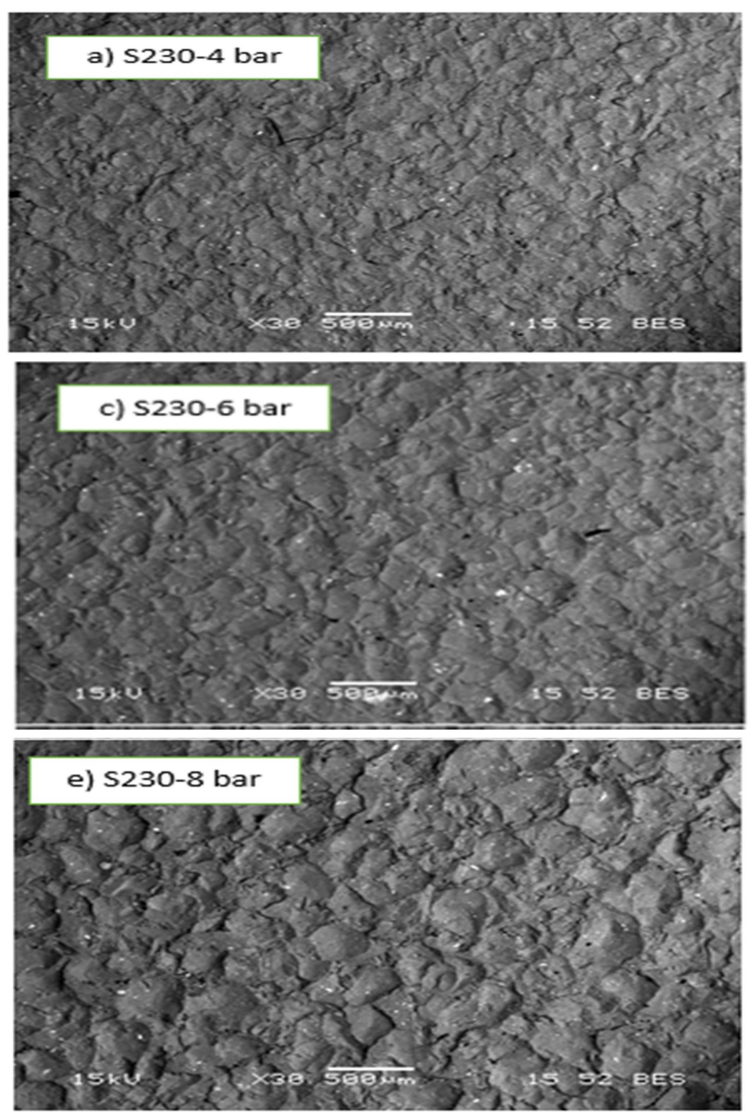

S230 $(0.6 \mathrm{~mm})$ ile dövülen yüzeylerde 4 bar'da yüzey pürüzlülüğü $R a=3.01$ iken, 8 bar sonunda $\mathrm{Ra}=4.93$ değerine çıkmaktadır. Yüzey pürüzlülüğündeki artış \%63.8'dir. S330 (0.84mm) ile dövülen numunelerde 4 bar'da $R a=3.51$ olan pürüzlülük değeri, 8 bar püskürtme basıncında $\mathrm{Ra}=5.17$ 'e yükselmiştir. Buradaki artış oranı ise \%47.3 olarak tespit edilmiştir.

\subsection{Yüzey özellikleri SEM incelemesi}

Bilyeli dövme ile birlikte yüzeyde plastik deformasyonlar meydana gelmiştir. Bilyelerin mevcut kütlesi ve hızıyla oluşturduğu kinetik enerji yüzeye aktarılmıştır. Yüzeyde kırılan tane yapıları sonunda yeni bir yüzey formu oluşmuştur. Şekil 10 'da bilyeli dövme işlemi uygulanan AA6061 T6 alüminyum alaşımının SEM görüntüleri verilmiştir. Numunelerin SEM görüntüleri Jeol marka JSM 6060LV model cihazda çekilmiştir.
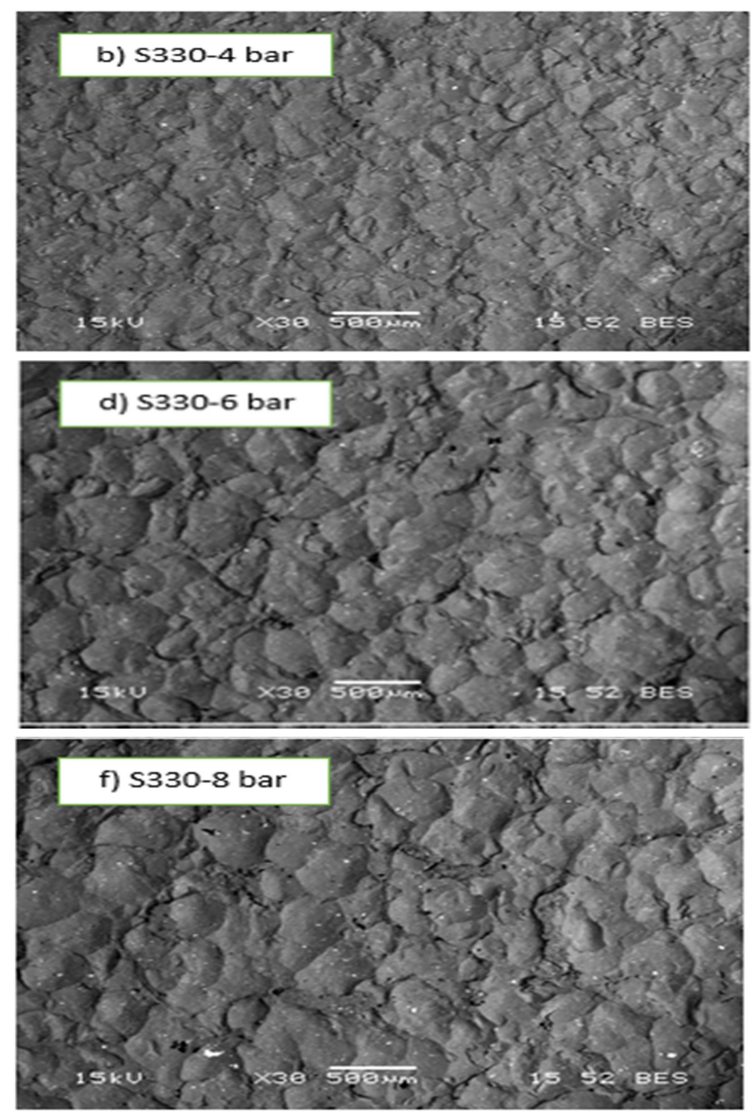

Şekil 10. Bilyeli dövme parametrelerinin SEM analizi a)S230 bilye-4 bar b) S330 bilye-4 bar c) S230 bilye- 6 bar d) S330 bilye- 6 bar e) S230 bilye- 8 bar f) S330 bilye- 8 bar 
Şekil 10'daki SEM görüntüleri incelendiğinde, S230 bilyede basınç arttıkça yüzeyde oluşan tepe-çukur oluşumları giderek belirgin hale gelmiştir. Aynı yorumu S330 bilye için yapmak mümkündür. SEM görüntüleriyle yüzey pürüzlülük değerleri birbirini desteklemektedir.

Bilyeli dövmede aynı basınç değerlerinde S330 $(0.84 \mathrm{~mm})$ bilyelerin $\mathrm{S} 230(0.6 \mathrm{~mm})$ bilyelere göre belirgin deformasyon bölgeleri oluşturmuştur. Bilye çapı arttıkça tepe-çukur oluşumlarının arttığı gözlemlenmektedir. Bu durum pürüzlülükle de örtüşmektedir.

\subsection{Bilyeli dövme işleminde yüzey örtme oranının malzeme üzerindeki etkileri}

Bilyeli dövme yönteminde önemli bir parametre olan yüzey örtme oranı, yüzeyin homojenliğinde önemli bir etkiye sahiptir (Avcu Y. Y., 2019). AA6061 T6 alüminyum alaşımı 6 bar basınç sabit tutularak iki farklı yüzey örtme oranında (\%100 ve \%200) dövülmüştür. Yüzey örtme oranında numune daha fazla bilyeli dövmeye maruz kalmaktadır. Tablo 7.'de sabit 6 bar püskürtme basıncında ve iki farklı örtme oranında dövülmüş numunelerin çekme dayanımı, yüzey pürüzlülüğü ve mikro sertlik değerleri verilmiştir. Yüzey örtme oranı arttıkça çekme dayanımı ve sertlik değerleri artarken, yüzey pürüzlülüğünde düşsme gözlenmektedir. Dövülmemiş halde 86 HV olan numuneler, sabit 6 bar püskürtme basıncı ve $\% 100$ örtücülükte S230 bilyelerle dövüldüğünde $\% 25$ sertlik artışı gözlenirken \%200 örtücülükte ise \%43.6 artış gözlenmiştir. Bilye çapı arttığında ise (S330) bu artış sırasıyla \%43.7 den \%55.2 ye çıkmıştır (Tablo 7).

Tablo 7. Farklı örtme oranında çekme mukavemeti, yüzey pürüzlülüğü ve sertlik ölçüm sonuçları

\begin{tabular}{ccccccc}
\hline SAE no & $\begin{array}{c}\text { Püskürtme } \\
\text { Basıncı } \\
\text { (bar) }\end{array}$ & $\begin{array}{c}\text { Yüzey örtme } \\
\text { oranı }\end{array}$ & $\begin{array}{c}\text { Çekme } \\
\text { Mukavemeti } \\
\text { (\%) }\end{array}$ & $\begin{array}{c}\text { Uzama } \\
\text { (M) }\end{array}$ & $\begin{array}{c}\text { Yüzey } \\
\text { Pürüzlülüğü } \\
\text { (Ra) }\end{array}$ & $\begin{array}{c}\text { Mikrosertlik } \\
\text { HV } \\
\text { (Dövülmüş } \\
\text { yüzey) }\end{array}$ \\
\hline \multirow{2}{*}{ S230 } & 6 & 100 & 319.9 & 16.2 & 3.23 & 107.50 \\
\hline \multirow{2}{*}{ S330 } & 6 & $\mathbf{2 0 0}$ & 328.0 & 14.7 & 3.11 & 123.50 \\
\hline & 6 & 100 & 324.4 & 14.7 & 5.13 & 123.60 \\
\hline
\end{tabular}

Şekil 11'de ise SEM analizi sonuçları yer almaktadır. Şekil 11.a ve Şekil 11.b incelendiğinde yüzey örtme oranı \%100'den \%200'e çıkartıldığında yüzey deformasyonu belirgin bir şekilde artmıştır. S230 çelik bilye ile dövülen numunelerde çekme dayanımındaki artış bu durumu desteklemektedir.

S330'luk büyük çaplı bilye ile dövülen AA6061 T6 malzemede örtücülük oranının artması çekme dayanımında daha düşük artış gerçekleşmiştir. Yüzey pürüzlülüğü (Ra) örtme oranının artması ile düşmektedir. Şekil 11.c ve Şekil 11.d incelendiğine yüzey örtme oranı \%100 den \%200 e çıkarıldığına malzeme yüzeyinde düzleşmeler göze çarpmaktadır. Fakat en iyi çekme dayanımı 6 bar püskürtme basıncında, küçük çaplı bilyede (S230/0.6mm) ve \%200 örtücülük oranında tespit edilmiştir. 

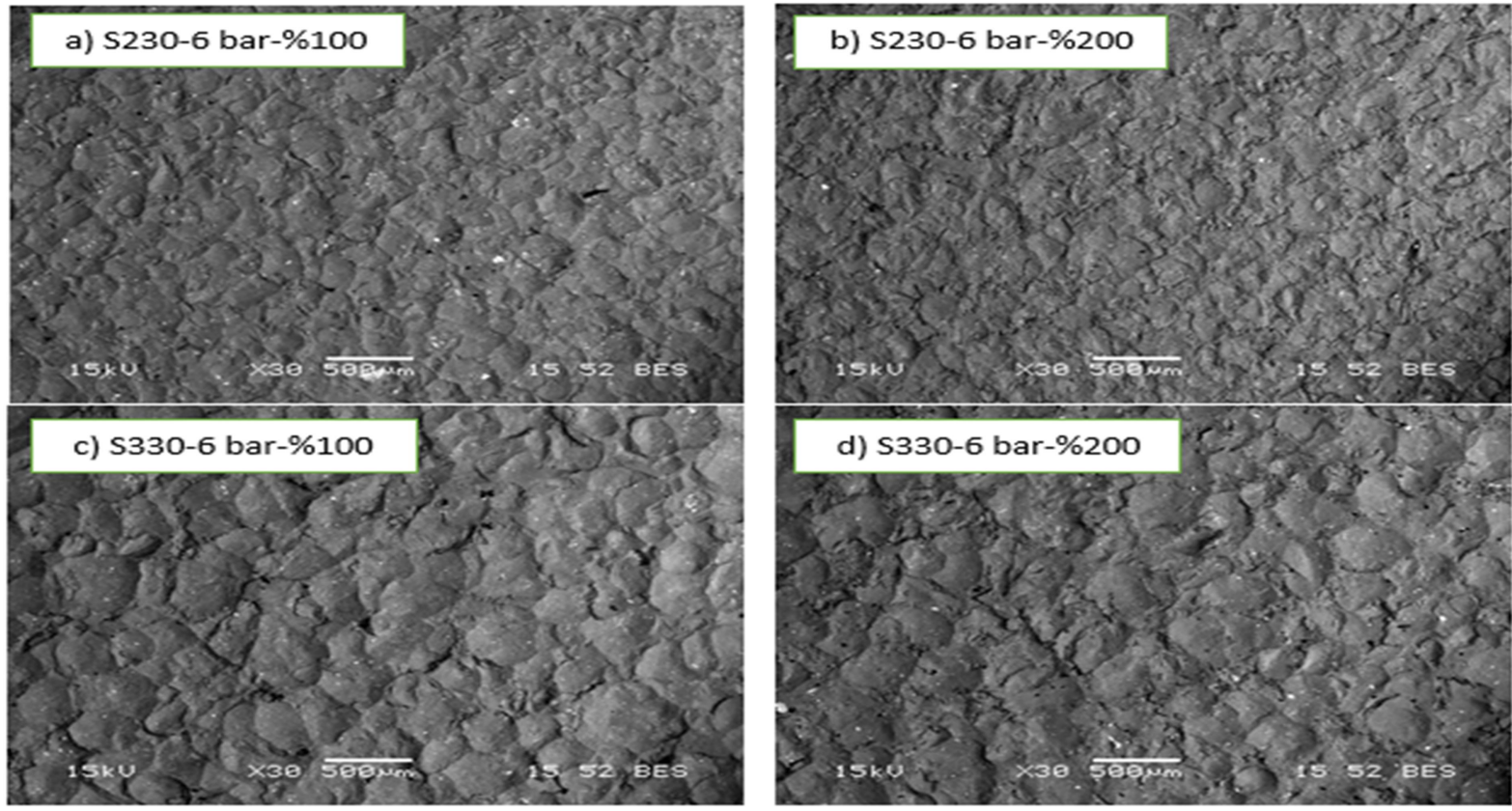

Şekil 11. Bilyeli dövme parametrelerinin SEM analizi

a) S230 bilye- 4 bar b) S330 bilye- 4 bar c) S230 bilye- 6 bar d) S330 bilye- 6 bar

\subsection{Sonuçlar}

Bilyeli dövme yöntemi ile AA6061 T6 alüminyum alaşımına S230 ve S330 bilyelerle 4, 6 ve 8 bar püskürtme basınçlarında dövme işlemi gerçekleştirilmiştir. Yapılan çalışma sonunda aşağıdaki sonuçlar elde edilmiştir.

- Bilye çapı arttıkça numunelerde çekme mukavemetinde artış, \% uzama değerlerinde ise düşme gözlemlenmiştir.

- Püskürtme basıncının artması ile düşük bilye çapında (S230/ 0.6mm) çekme dayanımı \% $3.8^{\prime}$ e ; büyük bilye çapında $(\$ 330 / 0.84 \mathrm{~mm})$ ise $\%$ 2.72'ye varan artışlar tespit edilmiştir. Çekme dayanımının dövülmemiş numuneye göre en yüksek olduğu değerler; düşük bilye çapında \%100 yüzey örtme oranında 8 bar basınçtaki dövme işleminde $\% 3.80$, küçük bilye çapında \%200 yüzey örtme oranında 6 bar basınçtaki dövme işleminde \%3.86 artış gerçekleşmiştir. Dövme işleminin etkisiyle \%100 yüzey örtme oranı ile tüm parametrelerde çekme dayanımında \%1 ila \%3.8 arasında artış tespit edilmiştir.

- Büyük bilye çapında ve yüksek püskürtme basıncında (8bar) çekme dayanımında bir miktar düşme kaydedilmiştir. Bunun muhtemel sebebinin malzeme yüzeyindeki mikro çatlakların oluşumundan kaynaklandığı düşünülmektedir.

- Yüzey örtme oranının artması (\%100'den $\% 200$ 'e) ile farklı bilye çaplarında yapılan dövme işlemi çekme dayanımını, mikro sertliği arttırmıştır. Yüzey pürüzlülüğünü ise azaltmıştır. Püskürtme basıncı 6 bar basınçta gerçekleştirilen deneylerde küçük bilye çapında ( $2230 / 0.6 \mathrm{~mm}$ ) yüzey örtücülük oranı \%100'den \%200'e çıkartıldığında çekme dayanımı \%2.3, dövülmemiş malzemeye göre ise \%3.86 artış göstermiştir. Büyük bilye çapında (S330/0.84mm) çekme dayanımı \%100 yüzey örtme oranı \%200'e çıkartıldığında \%0.7; dövülmemiş malzemeye göre \%3.39 artış tespit edilmiştir. Büyük bilye çapındaki dayanımdaki artış daha az gerçekleşmiştir.

- Yüzey sertliği, \%200 örtücülükte ve küçük bilye çapında dövülmemiş numuneye göre $\% 43.6$ ya kadar artış gösterirken, büyük biye çapında $\% 55.2$ ye kadar çıkmaktadır.

- Yüzey pürüzlülüğü her iki bilye çapında da basıncın artması ile artış göstermiştir. Bilye 
çapı arttıkça yüzey pürüzlülüğü artmıştır. Düşük bilye çapında basıncın iki kat arttırılması (4 bar'dan 8 bar'a) ile yüzey pürüzlülüğündeki artış \%63.8 olurken, büyük bilye çapında bu artış \% 47.3 olarak tespit edilmiştir.

- Numunelerin SEM görüntüleri incelendiğinde bilye çapı arttıkça plastik deformasyon ve tepe-çukur oluşumunun artışı gözlenmiştir. Püskürtme basıncı arttıkça yüzeyde oluşan tepe-çukur oluşumları daha belirgin hale gelmiştir. Örtücülük oranı arttıkça numune yüzeyinde sertliğin artması ve pürüzlülüğün düşmesi ile daha düzgün bir yapı gözlenmektedir. Bu daha önce yapılmış literatür çalışmalarıyla uyum göstermiştir.

\section{Kaynaklar}

Alkan, Z., 2014. Alüminyum Alaşımlarında Bilyalı Dövmenin Fiziksel, Mekanik ve Yüzey Özelliklerine Etkisi, Doktora Tezi, Süleyman Demirel Üniversitesi, Fen Bilimleri Enstitüsü, Isparta, ss.101.

Alkan, Z., Varol, R., and Server, R. 2016. Bilyeli dövme uygulanmış AA1050 alüminyum malzemenin metalografik incelenmesi. Süleyman Demirel Üniversitesi Fen Bilimleri Enstitüsü Dergisi, 20 (5), 524-529.

Avcu, E., 2018. Bilyalı dövme parametrelerinin AA7075 T6 alüminyum alaşımının yüzey altı özelliklerine etkileri. GU J Sci, Part C, 6 (4), 741-752.

Avcu, Y. Y., 2019. Ti6Al4V Titanyum Alaşımın Bilyalı Dövme Sonrası Aşınma Davranışının İncelenmesi. Doktora Tezi, Kocaeli Üniversitesi, Fen Bilimleri Enstitüsü, Makina Mühendisliği Bölümü, Kocaeli, ss.173.

Ay, ì., \& Sakin, R., 1988. Kumlama ile Parça Temizleme ve Bilyalı Dövme Prosesi. Makina \& Metal Teknolojisi, 68-72.

Başer, T. A., 2012. Alüminyum Alaşımları ve Otomotiv Endüstrisinde Kullanımı. Mühendis ve Makina. Mühendis ve Makina, 53 (635), 51-58.

Chen, B., Huang, B., Liu, H., Li, X., Ni, M., and Lu, C. 2014. Surface Nanocrystallization Induced By Shot Peening And Its Effect On Corrosion Resistance of 6061 Aluminum Alloy. J. Mater. Res., 29 (24), 3002-3010.
Coşkun, K., 2002. Hadde Alüminyum Alaşımlarının Uçaklarda Kullanılması. Yüksek Lisans Tezi, İstanbul Teknik Üniversitesi Fen Bilimleri Enstitüsü, İstanbul, ss.155.

Fetaş Metalurji . (2021, Mayıs 5). Fetaş Metalurji Web sitesi: $\quad$ https://www.fetasmetalurji.com adresinden alındı.

Markovina, R., Blagojević, B., and Ban, D., 2008. Investigation of Influential Parameters on ShotPeening of Aluminum Alloys. 12th International Research/Expert Conference. İstanbul.

Patil, S. S., S. P., S., S. K., \& S., S. A. 2018. A Review on Influence of Various Technological Processes on Mechanical Properties of Aluminum Alloys. IOP Conf. Series: Materials Science and Engineering.

Sathyajith, S., \& Kalainathan, S., 2012. Effect of Laser Shot Peening on Precipitation Hardened Aluminum Alloy 6061-T6 Using Low Energy Laser. Optics and Lasers in Engineering (50), 345-348.

Ünal, O., \& Varol, R., 2014. Almen Intensity Effect on Microstructure and Mechanical Properties of Low Carbon Steel Subjected to Severe Shot Peening. Applied Surface Science (290), 40-47.

Varol, R., 1990. 2024 Alüminyum Alaşımının Yorulma Ömrü Üzerine Farklı Bilyeli Dövme İşlem Parametrelerinin Etkisi. Doktora Tezi, Selçuk Üniversitesi Fen Bilimleri Enstitüsü, Konya. 